$\mathbb{P}$ periodica polytechnica

Mechanical Engineering

$54 / 1(2010) 49,56$

doi: 10.3311/pp.me.2010-1.08

web: http://www.pp.bme.hu/me

(c) Periodica Polytechnica 2010

RESEARCH ARTICLE

\section{Development of 3E tillage system and machinery to challenge climate change impacts}

\author{
János Péter Rádics / István J. Jóri
}

Received 2011-01-10

\begin{abstract}
The main influences of climate change are the increased frequent occurency of heavy rainfall and drought season in our region. We should anticipate that climate change will become an additional driver for change in tillage practice. The main goals
\end{abstract} are:

- The maximum infiltration of precipitation (rainfall) should be reached (decreasing of runoff water and evaporation);

- The maximum rate of water should be hold in the soil (decreasing the leaching effect and increasing water storage capacity).

Our $R+D$ work wants to solve these problems to develop a new method named $3 E$ environment-oriented tillage system which has the advantages of saving Energy, controlling Erosion, decreasing Emission. To validate the new method, the basic machines for the new system were also developed.

Decisions relating to the use of new tillage system will be made in the context of both the longer term strategic response to climate change, and the shorter term practical response to annual weather patterns.

\section{Keywords}

3E tillage $\cdot$ mulch-cultivator $\cdot$ mulch-loosener $\cdot$ mulchseeder $\cdot \mathrm{CO}_{2} \mathrm{flux}$

\section{Acknowledgement}

The authors wish to acknowledge the instrumentation and the assistance in the field tests for the Hungarian Institute of Agricultural Engineering and the financial grant from the National Development Agency (GVOP-3.1.1-2004-05-0418/3.0).

\section{János Péter Rádics}

Department of Machine and Product Design, BME, H-1111 Budapest, Múegyetem rkp. 3, Hungary

e-mail: Radics.Janos@gt.bme.hu

\section{István J. Jóri}

Department of Machine and Product Design, BME, H-1111 Budapest, Múegyetem rkp. 3, Hungary

e-mail: Jori.Istvan@gt3.bme.hu

\section{Introduction}

Climate change will affect land and soil directly as well as indirectly through impacts on land use. Changes in the use and management of land are likely to have bigger effects on soils than climate change itself [7].

Knowledge of climate change is an obvious first step to maintain or improve production and land management in the future. Within this context, changing the intensity, timing, or form of tillage may be one of the management options more readily implemented to assist with adaptation to climate change. Other more extreme measures may need to involve new or modified production systems, or even structural change to alter land use [12].

The soil condition and the environment features should be controlled for the sustainable crop production by:

- The maximum infiltration of precipitation (rainfall) should be reached (decreasing of runoff water and evaporation);

- The maximum rate of water should be hold in the soil, (decreasing the leaching effect and increasing water storage capacity);

- The maximum rate of stored water could be used by plants [13].

These requirements could not be realized by the conventional tillage system usually. Thus different non inversion tillage system was developed on the end of last century in Europe and the USA [2]. The most important advantage of conservation tillage is significantly less soil erosion. Fuel and labor requirements are also reduced with conservation tillage. However, recent concern for global climate change reemphasizes the importance of conservation tillage and how it can be implemented on many soils to help reduce soil $\mathrm{C}$ losses. Soil and crop residue management systems can play a major role in greenhouse gas emissions need to be optimized to minimize impact on climate change [9]. To study the mulch corresponding effect (erosion, moisture holding, $\mathrm{CO}_{2}$ flux reducing) of different tillage tools (compact disc harrow, cultivator), we have to be able to rank these machines by suitability of the tillage conditions. 


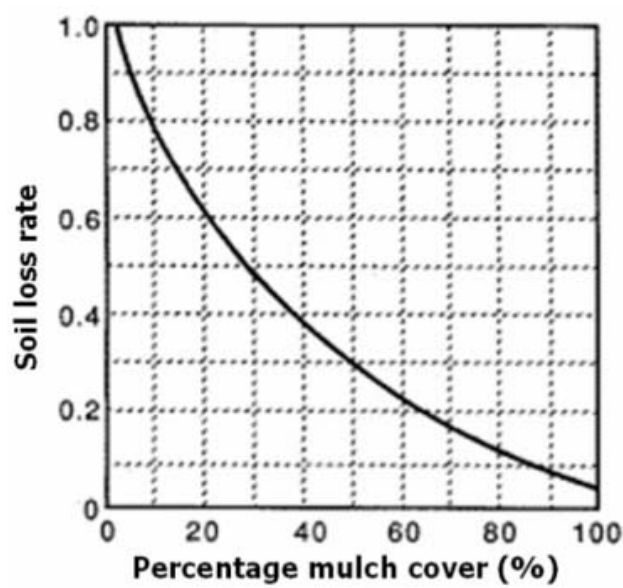

(Source: McCarthy et.al. 2005)

Fig. 1. Effect of percentage mulch cover on soil loss rate

Conservation tillage systems represent alternatives at a time when economics requires flexibility in crop production. Thus, more information is needed to advance the current understanding of how agricultural production systems can be modified to enhance environmental quality. Many aspects of improved soil management research needs are related to the impact of land use as affected by tillage methods. Sustainability from a soil tillage viewpoint can evolve towards greater efficiency of resource use, and can develop and maintain a harmony between crop production technologies and soil environment [3].

\section{Material and method}

Developing the environment-oriented tillage system we have to know how the sub-systems are working. For example the site specific system involves the crop production, the residue, the fertilization and the integrated plant protection sub-systems [1]. Therefore field measurements were done to get information about percentage level of crop residue, amount of soil emitted $\mathrm{CO}_{2}$, fuel consumption and erosion reducing effect of different tillage treatments. The main goals were determined from the results of completed measurements, which are the well defined milestones for the machine development.

Tab. 1. Residue of tillage systems

\begin{tabular}{lc}
\hline Field operation & Residue (\%) \\
\hline Conventional tillage & $<15$ \\
Reduced tillage & $15-30$ \\
Conservation tillage & \\
- No-till & $>30$ \\
- Ridge-till & $>30$ \\
- Mulch-till & $>30$ \\
\hline
\end{tabular}

To create a new system we have to change the conventional single machine by a new combined one. Combination implements have become very popular because they can perform more than one tillage operation in a single pass, thus reducing the number of trips across a field. Also, they can be equipped and adjusted to leave plant residue on the soil surface rather than burying it in the soil. Consequently, they fit very well into the trend of reduced or conservation tillage.

These new machines have a special name like this: mulchtiller, conser-till, soil saver, cutter chisel plow, disk-ripper etc. in the US market. To find the suitable components for this machine the following aspects should be taken into consideration: soil type and condition; the residue type, condition and amount; the tillage season (spring, summer, winter).

The most important part of the environment-oriented tillage system is the residue management. The basic requirement (more than $30 \%$ coverage) of the American Food Security Act (1985) can be produced by different tillage operation (Table 1 ).

From these systems the mulch-tillage system has tradition and good chance to spread in Hungarian agriculture.

\section{Results}

The result of our latest $\mathrm{R}+\mathrm{D}$ work was a new system named $3 E$ environment-oriented tillage (Fig. 8) system which has the following advantages:

- saving Energy

Efficient tillage tools and machines are the prime importance in operating cost. The recent years conditions made it even more important to have information about energy consumption of tillage treatments. This characteristics can be well defined by the areal fuel consumption or by the direct measurement of traction resistance. Table 2 specifies the fuel consumption for different tillage machines. These values from prior measurements are the fundamental points by the selection of the $3 \mathrm{E}$ system adaptable implements in the consideration of energy consumption.

Reducing of tillage tools and treatments is needed, because conventional crop production methods require 9 to 11 operations for pre-plant field preparation at $18 \%$ to $24 \%$ of production costs [10]. There is a potential to eliminate deep tillage and to decrease soil preparation operations by as much as $60 \%$ [6].

- decreasing Erosion.

Measurements were made to determine the effect of tillage applied perpendicular or parallel to slope on the resulting runoff volumes, and the soil losses (Fig. 2). Results are shown on Fig. 3 It can be generally stated, that the direction of tillage is a similarly important factor as the slope gradient and rainfall intensity on the amount of runoff and soil loss.

Soil erosion potential is increased or decreased with the amount of crop residue. The erosion control benefits of environment oriented tillage systems mostly depend on how much protection is available at different periods of the year. It is very important to control crop residue by every tillage treatment. Most of the erosion can be reduced by leaving a residue cover of $30 \%$ on the field. Environment oriented tillage practices are resulting the expected crop residue cover (Fig. 4), and implement settings are allowing the control of crop residue level. 
Tab. 2. Fuel consumption for different tillage treatments

\begin{tabular}{lllllll}
\hline \multirow{2}{*}{ Operation } & \multirow{2}{*}{ Machine } & \multirow{2}{*}{ Pass number } & \multicolumn{2}{l}{ Time } & \multicolumn{3}{l}{ Fuel consumption } \\
\cline { 5 - 7 } & & & $\mathrm{h}$ & $\%$ & $\mathrm{~kg}$ & $\%$ \\
\hline Primary tillage & $\mathrm{A}$ & 1 & 63,00 & 100,00 & 1579,00 & 100,00 \\
& $\mathrm{~B}$ & 1 & 54,00 & 85,71 & 1465,00 & 92,78 \\
& $\mathrm{C}$ & 1 & 50,00 & 79,36 & 1480,00 & 93,73 \\
\hline Secondary tillage & $\mathrm{A}$ & 4 & 68,00 & 100,00 & 1917,00 & 100,00 \\
& $\mathrm{~B}$ & 3 & 44,00 & 64,70 & 1240,00 & 64,70 \\
& $\mathrm{C}$ & 2 & 23,50 & 34,60 & 656,00 & 34,20 \\
\hline Total & $\mathrm{A}$ & 5 & 131,00 & 100,00 & 3496,00 & 100,00 \\
& $\mathrm{~B}$ & 4 & 98,00 & 74,80 & 2945,00 & 84,20 \\
& $\mathrm{C}$ & 3 & 73,50 & 56,10 & 2136,00 & 61,10 \\
\hline
\end{tabular}

A - RÁBA - IH - moldbord plow - Working depth : $18-20 \mathrm{~cm}$

B - RAU - 18- mounted cultivator - Working depth : $18-20 \mathrm{~cm}$

C - RABEWERK - trailed cultivator - Working depth : $18-20 \mathrm{~cm}$

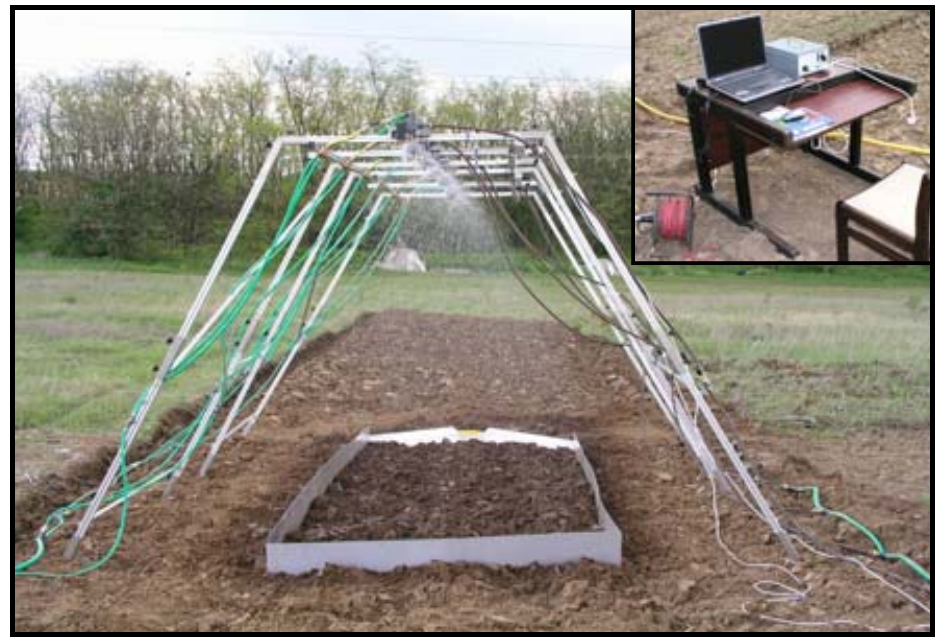

Fig. 2. Rainfall simulation on different plots

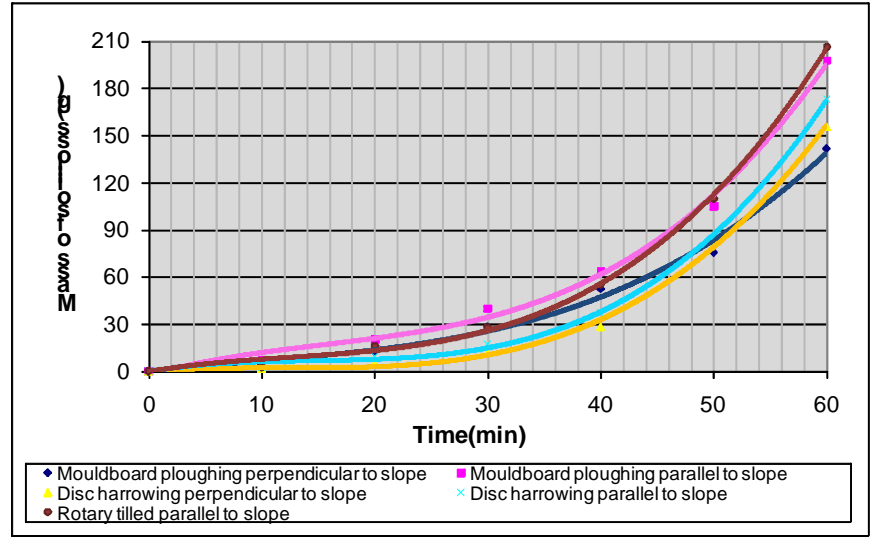

Fig. 3. Mass of soil loss on different tillage treatment plots after $60 \mathrm{~mm} / \mathrm{h}$ rainfall in function of time

- reducing Emission

Erosion control is not only important in relation of crop residue management. The intensive tillage, like moldboard ploughing inverts most of the residue into the soil which feeds a microbial population explosion. If most residues are left on the soil surface, only a small portion is in close contact with the soil moisture and can be available to microorganisms.
Figs. 5. 7 are representing the $\mathrm{CO}_{2}$ flux from soil after different tillage treatments. These results from prior measurements [8] are the grounds to establish importance of emitted greenhouse gases from the soil.

$\mathrm{CO}_{2}$ emission inducing microbial activity is influenced by weather conditions also. First of all the temperature has a great effect on soil $\mathrm{CO}_{2}$ flux. Under $10^{\circ} \mathrm{C}$ soil temperature, there is no significant difference between $\mathrm{CO}_{2}$ exchange of investigated tillage methods.

The most significant relations are established by intensity of tillage on soil $\mathrm{CO}_{2}$ emission. Tillage intensity and compaction of soil after tillage have the most intensive effect on the accumulation and loss of soil carbon and therewith on soil organic matter. Intensive tillage increases the soil porosity and larger pore size allows larger emission of soil $\mathrm{CO}_{2}$ from the soil.

The $3 E$ environment-oriented tillage system comprises the possibility of managing soil $\mathrm{CO}_{2}$ emission, erosion and energy consumption.

The basic machines of the new system: mulch-cultivator, mulch-loosener and mulch-seeder.

3.1 Agro-technical and technical requirements of mulchcultivator/loosener

The combined machines of mulch tillage have to do the following operations:

straw/corn stalk chopping

- soil loosing and crumbling

- mulch making (residue incorporation)

- leveling and finishing .

The suitable tools for every operation can be found in Table 3.

The most suitable geometrical and design specification of different tools for every operation depend on the soil type and condition was determined by researcher. Thus our goal in this project is to select the right tools for the best combination. 


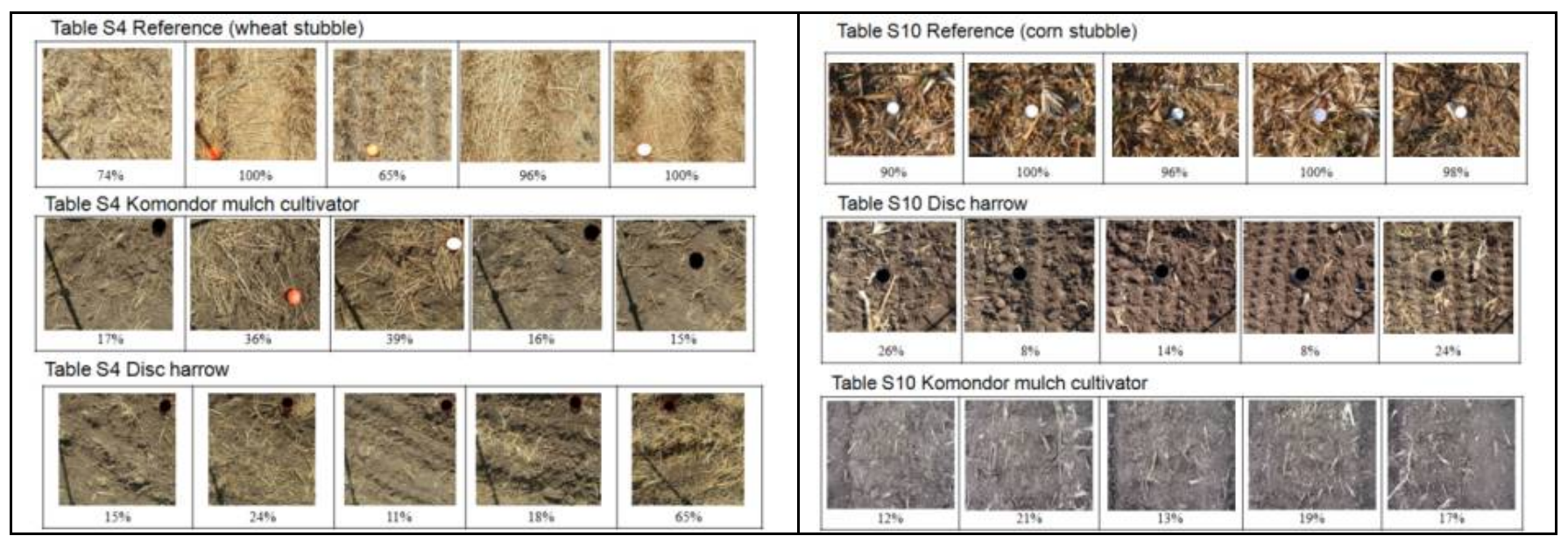

Fig. 4. Percentage level of crop residue after different tillage treatments

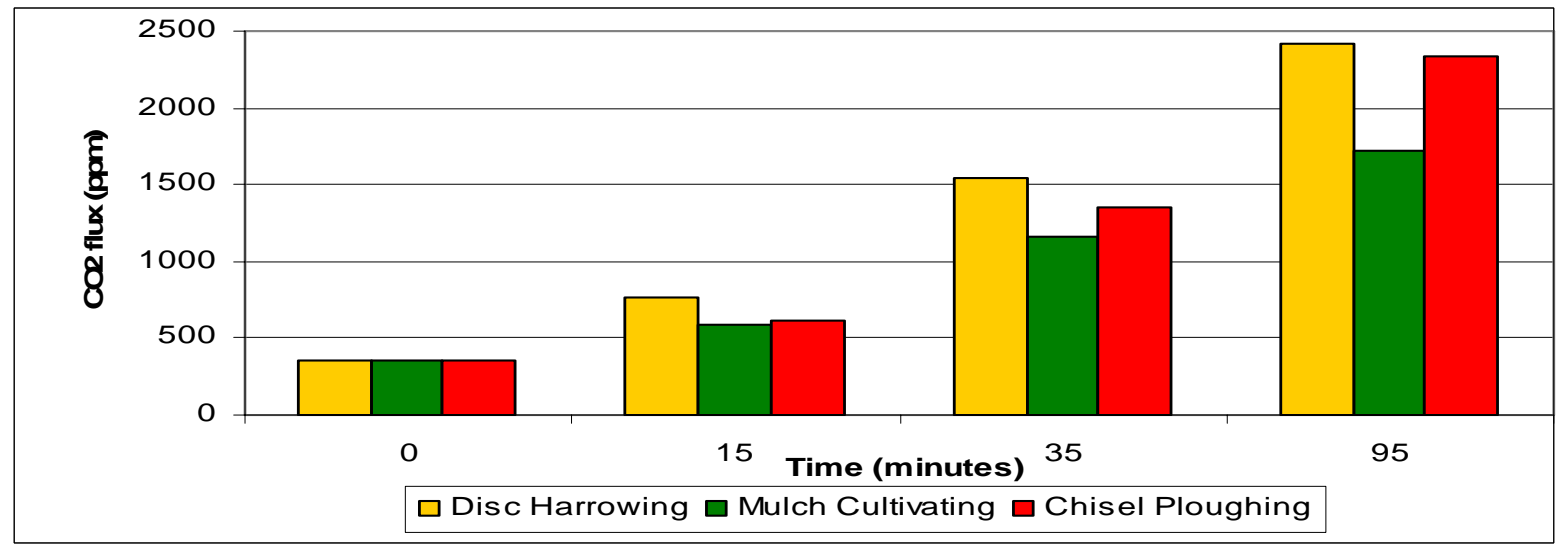

Fig. 5. $\mathrm{CO}_{2}$ flux versus time after stubble mulching

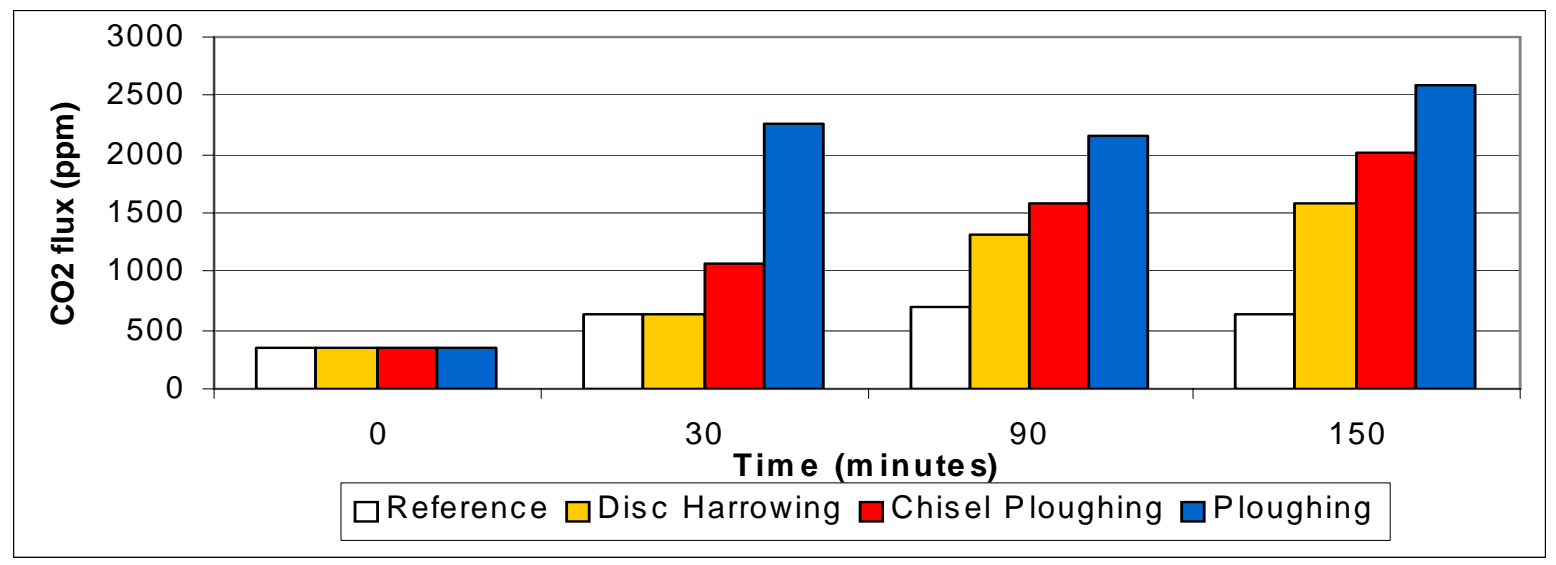

Fig. 6. $\mathrm{CO}_{2}$ flux versus time after primary tillage operations

Tab. 3. Tools of mulch cultivator/loosener

\begin{tabular}{llll}
\hline Chopping & Loosening/pulverizing & Mulching (incorporating) & Levelling, finishing \\
\hline Shredder (PTO) & Chisel plough & Disc harrow & Crumbling harrow \\
Disc & Cultivator & Rotary harrow & Roller \\
Disc harrow & -sweep & Rotary harrow (PTO driven) & Spring harrow Knife roller \\
Rotary harrow & -share & & Rubber roller \\
Knife roller & Harrow & & \\
& -rigid tine & & \\
& -spring tine & & \\
\hline
\end{tabular}




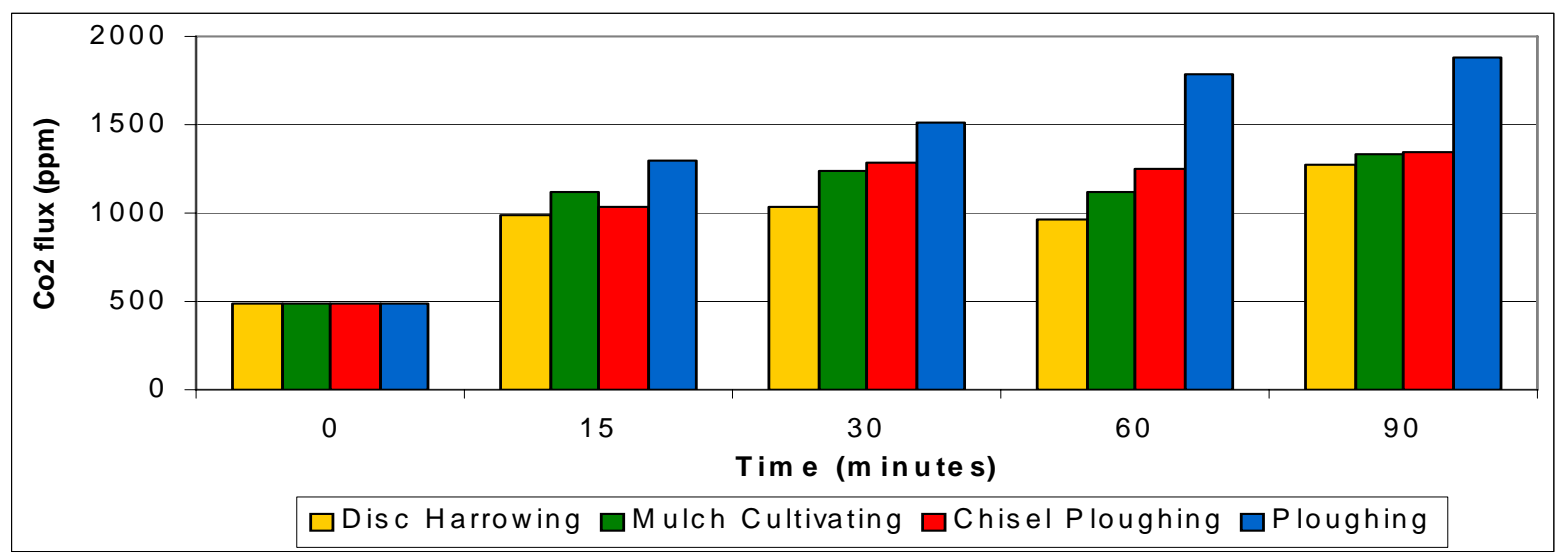

Fig. 7. Secondary tillage $\mathrm{CO}_{2}$ flux versus time after on different primary tillage pre- treatment plots

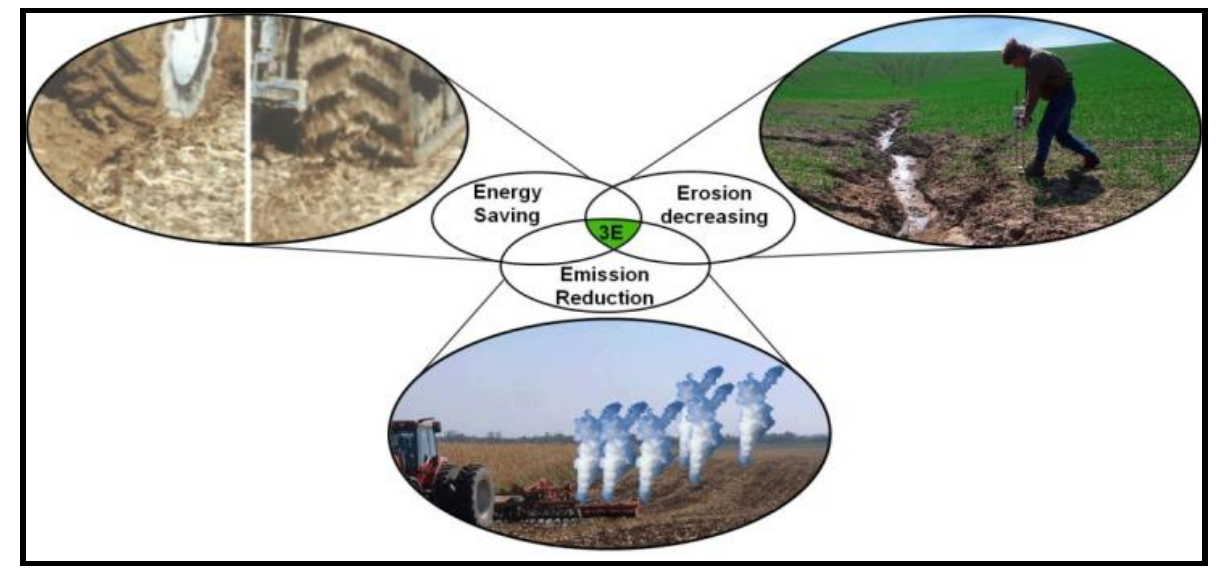

Fig. 8. Environment-oriented tillage (3E) system

Based upon above requirements the developments of the SX MulchMaster cultivators and SX disc ripper have successfully been completed (Figs. 12,13). These equipments are in serial production since the beginning of 2009.

\subsubsection{SXH Mulch Master cultivator}

The SXH Mulch Master cultivators are a family of primary tillage tools for conservation tillage that are suitable for effectively cutting residue and incorporating it into the top soil in a single pass. The new cultivator features spring loaded shanks that may accommodate a wide variety of tillage tools including sweeps, twisted shovels, chisel spikes etc., which allow it to be effectively used for managing corn or wheat stubble.

The advantages of the Mulch cultivator

- A broad range of interchangeable tillage tools offers a variety of setups, which enable the application of the cultivators in $a$ range of tillage practices.

- Variable rate of residue incorporation through equipment setup and tillage tool combinations.

- Through packing the top soil, the creation of a mulch layer, and the incorporation of residue in the top soil, the application of this implement increases the moisture retention capacity of the soil.
- Using the twisted shovels the cultivator breaks the hard layer of the soil created by the frequent use of disc harrows, increasing the soil's water absorption capability.

- With the 16" wide sweeps (which feature constant cutting width) the cultivator cuts the soil in its full working width, thus providing effective weed control in addition to quality wheat stubble management.

- Increases yield potential by increasing the concentration of organic matter in the root zone through residue incorporation.

- The cultivator provides higher yield performance at lower fuel consumption and power demand when compared to plowing. As it also allows for reduced tillage farming, it offers an energy efficient alternative for conservation tillage.

\subsubsection{SX disc ripper}

The disc ripper is a heavy duty tillage implement that enables adequate loosening of the soil (up to a depth of $45 \mathrm{~cm}$ ) while cutting and incorporating plant residue into the soil in a single pass. The implement is suitable for the management of wheat and corn stubbles as well, and with periodic use (every 2-3 years) it can substitute the use of discs and plows as a part of conservation tillage practice.

The high-clearance subsoiler shanks of the implement are positioned between two gangs of notched discs to allow efficient 


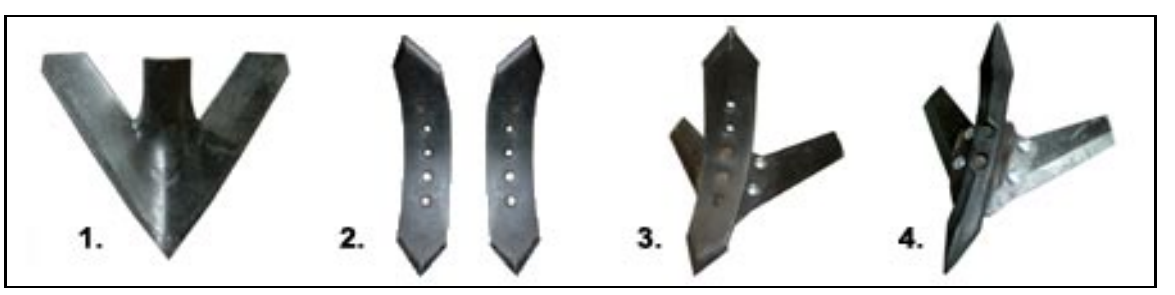

Fig. 9. Variable tools for the mulch cultivator

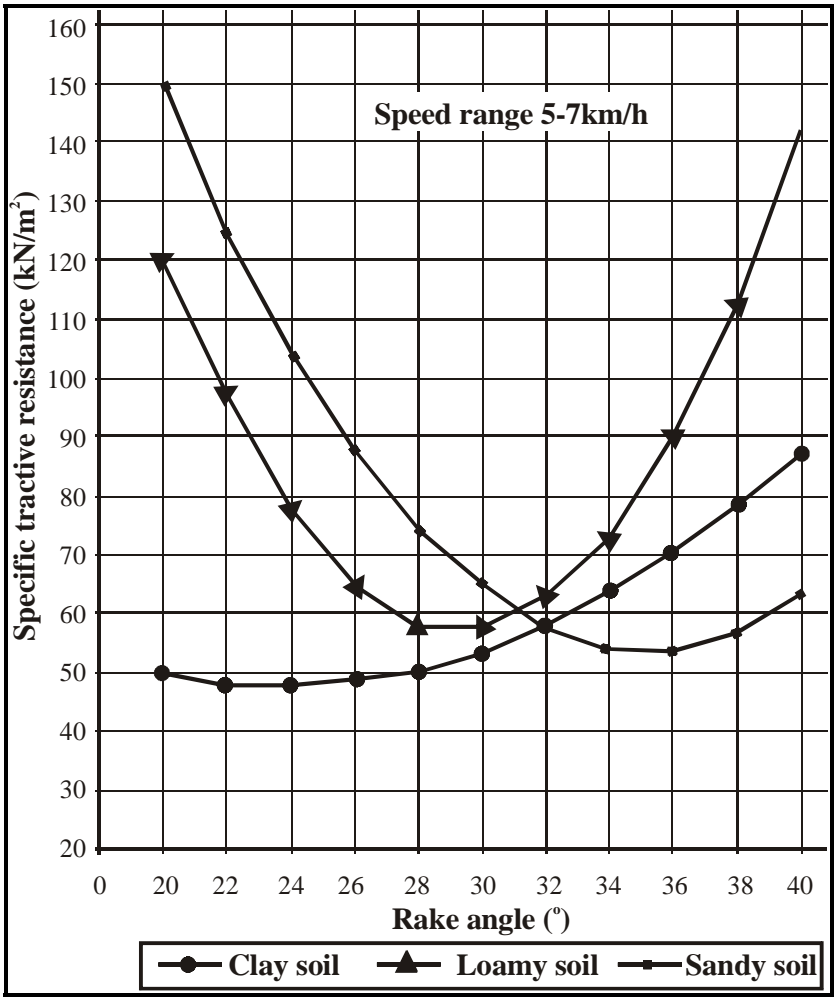

Fig. 10. Specific tractive resistance of rake angle

residue cutting and a smooth soil surface behind the implement. The subsoiler shanks of the disc ripper are equipped with $200 \mathrm{~mm}$ wide wings for efficient soil loosening across the working depth and working width. The tillage operation performed by the disc ripper is finalized by the Cambridge rollers which efficiently pack the surface of the soil to prevent moisture loss of the soil.

3.2 The agro-technical and technical requirements of mulch-seeder

The functional structure of mulch seeder depends on their main task: seeding (cereals) or planting (corn/sunflower) or both. The field (farm) size has a great influence also, because there is a big difference in the farm area between European and North-American (Australian) one.

The characteristics of the European mulch-seeder

The main requirement of this machine is a one pass seedbed preparation and sowing. In West- and North Europe the first reason of development was the agro-technical requirement (special soil and weather condition) and recently are rising the economy and ecology demand.

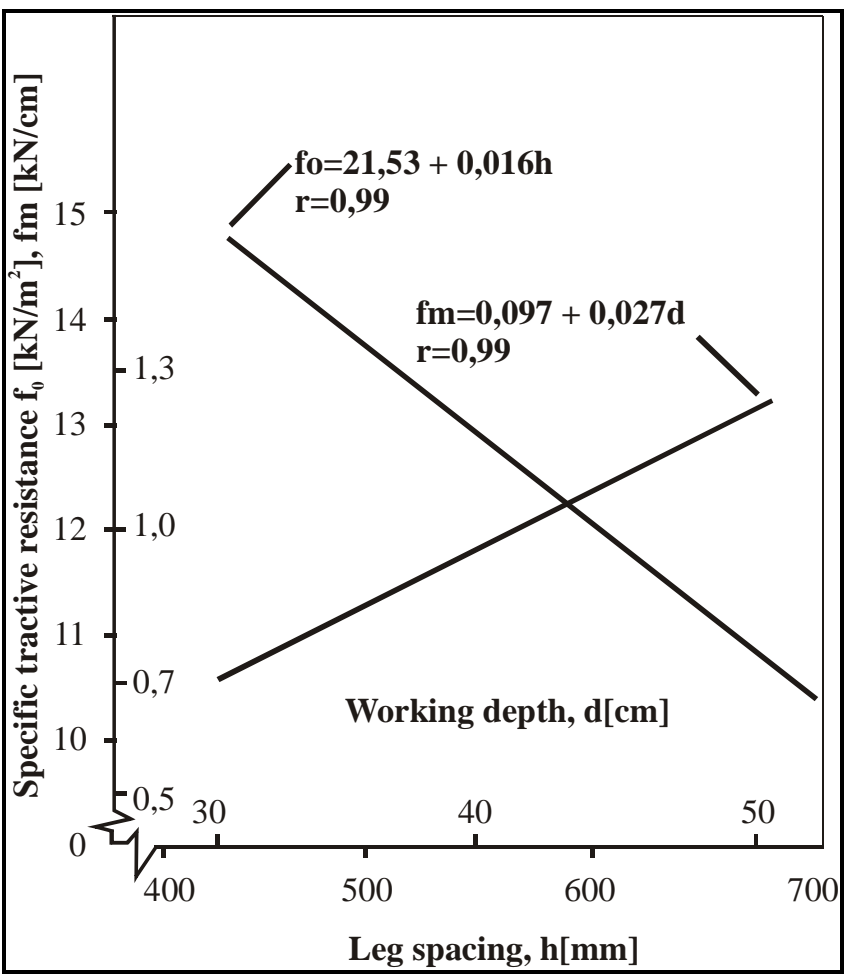

Fig. 11. Specific tractive resistance vs. working depth and leg spacing

In the small scale farming system the basic, so called standard machine is a PTO driven tillage equipment (rotary harrow, rotary tiller) and coupled seeder. All European manufacturer has his own product.

In the big scale farming system the combined heavy seedbed preparation-seeding machine is the right solution. In the latest time an interesting development process was observable. At the very beginning the independent tillage and seeding machine was coupled (e.g. Lemken Solitair). Later the seeding unit was placed on the tillage machine (e.g. Pöttinger Terrasem, Amazone Cirrus, Horsch Airseeder).

The next developing step was a brand new combined machine in which the tillage and seeding unit was changeable by local demand (e.g. Amazone Airstar, Horsch double disc drill, Rabewerk mulch-drill, Accord msc).

At last can be mentioned the very special seeding machines which do not need tillage unit, only a single tillage tool - like disc blade - can be found on them for seedbed opening (e.g. Vaderstad Rapid, Amazone Primera, Kuhn Fastliner).

The characteristics of the American mulch-seeder

The development work of American mulch seeder has two 


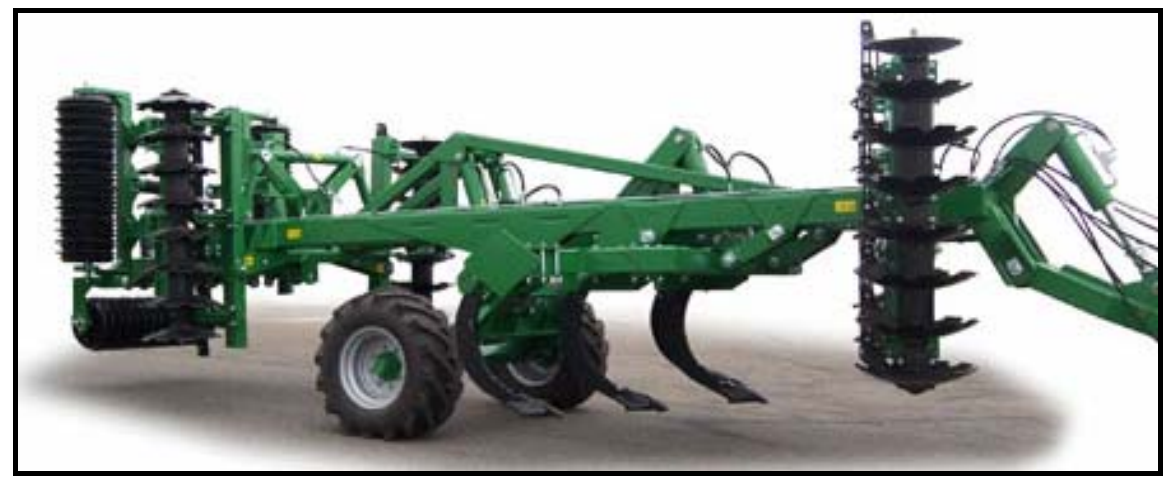

Fig. 12. SX MulchMaster cultivator

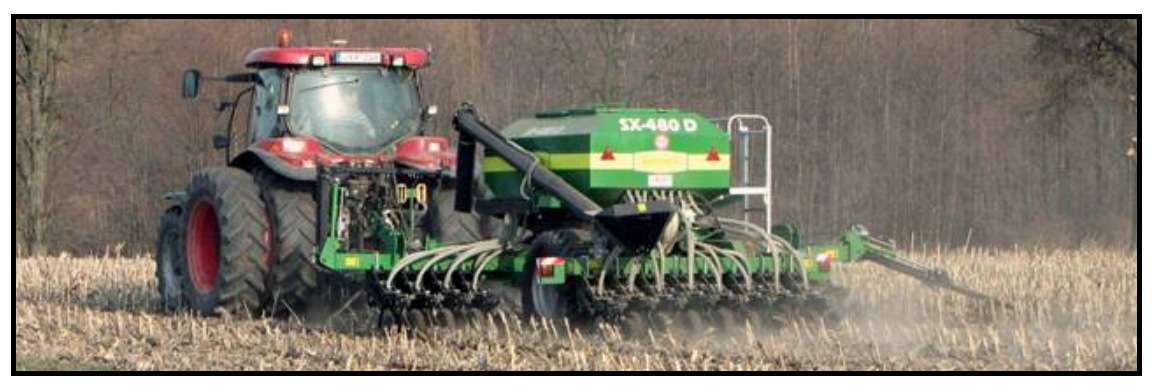

Fig. 13. SX disc ripper

directions: the ideas for cereal came from Canada and the ideas for corn came from Corn Belt, USA.

The first machines in the extensive Canadian system were a coupled field cultivator - mechanical seeding machine, which was replaced later, when the air-seeding system was developed, the new machine named air seeder consists of two parts generally: the cultivator and the air cart.

There are two systems of air seeder:

- the air cart tow-behind cultivator

- the air cart tow-between tractor and cultivator.

The main advantage of the first version is the better manoeuvrability and of the second one is the lower soil compaction. The best air carts are designed with split tank to deliver seed and fertilizer quickly, efficiently and accurately.

The openers placed on three (four) rows flexible frame cultivator are as follows.

- Hoe point or knife opener

- Shank opener

- Sweep opener.

All types can be built to single or double shoot version.

According to these criteria the SX-480D air seeder has been developed and the prototype unit is being field tested with promising results (Fig. 14).

\subsubsection{SX Mulch Seeder}

The new seeder is suitable for up-to-date seeding technology for seeding fields covered with high amounts of plant residue. Thus, in addition to conventional tillage practices, the new seeder may be used for mulch tillage or zero tillage farming as well. With low tractor power demand the disc coulters of the implement enable economic operation, and with minimal soil disturbance they also help minimizing the carbon dioxide emission of the soil as well as loss of moisture.

The seeder's coulter units are equipped with individual packing wheels with adjustable down pressure between 500-2000 $\mathrm{N}$. The generous $780 \mathrm{~mm}$ ground clearance of the toolbar ensures plugging free operations even in high-residue fields. The disc coulters and the fitted trash plates have been designed to allow high field performance and reliable operation at working speeds of $7-14 \mathrm{~km} / \mathrm{h}$.

Further improvement of the cultivator frame so as to accommodate broad range of coulter systems for various field conditions is being in progress.

\section{Conclusion}

4.1 Generally design requirements of tillage tools and implements for 3E environmental oriented tillage system, can be summarized as follows:

- to save Energy, the most important demand is, to develop the adequate implements by the prime importance of operating cost. To select from available tools, energy consumption can be determined by areal fuel consumption or by direct measurement of traction resistance.

- to decrease Erosion, it is required, to decrease the percentage level of crop residue, to lower the soil erosion potential. Reducing of wind and water erosion needs the control of crop residue level, through the applying of required operation with 


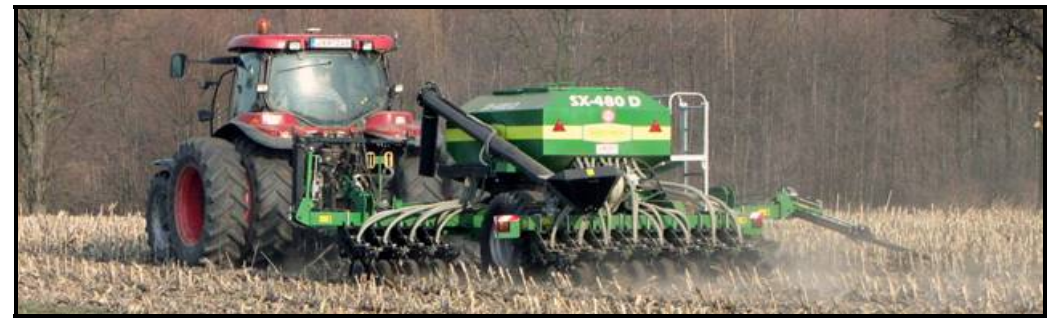

Fig. 14. SX-480D Mulch Seeder

the suitable machine with the adequate working parameters.

- to reduce Emission the intensity of tillage is in focus. It has the most significant influence on soil $\mathrm{CO}_{2}$ emission, but effect of weather and soil conditions, mass of crop residue inverted and compaction are also well observable. Based upon these requirements the optimal combination of tools should be reached.

\subsection{Design requirements of mulch-cultivator/loosener can} be summarized as follows:

- the machines developed for non-inversion tillage system should be a combination of equipment like these: disc coulter, disc harrow, chisel plough or subsoiler, roller or crumbler;

- to develop a mulch cultivator/loosener can be made by two different ways. In the first case two standard, single equipments (e.g.: disc harrow and subsoiler) coupled behind each other. Thus the machines can be used alone for original task or altogether for a new environment-friendly way. In the second case a brand new machine is born by building them together in the factory. After that the parts of the new machine will not be used separately, but the common performance and energy efficiency will be better.

- in our condition two different types of the new machine were developed depending on the cropping system. In the machine for the fall tillage the cultivator/chisel unit is between or behind the disc harrow rows and the machine has no finishing unit. In the machine for summer tillage the cultivator/chisel unit is between the disc harrow rows and the machine has to have finishing unit.

\subsection{Design requirements of mulch-seeder can be summa-} rized as follows:

- There is a basic construction difference between the European and the North-American design. The majority of European construction consists of two different - tillage and seeding parts. The seedbed preparation unit can be a cultivator or disc harrow (recently compact type) or a PTO driven rotary harrow but all versions have finishing tools. The seeding unit placed behind the tillage part is an air system usually.

The American construction first of all in the cereal production, is using the air-seeding/drilling method. In this system the tillage unit is a field cultivator and the seeding/drilling unit is an air seeder.
- The main parts of the air seeder:

- air-cart (with seed tank)

- field cultivator (with openers).

The air-cart can be tow-behind and tow-between (tractorcultivator) type. The air-cart has a split type tank to deliver seed and fertilizer. The cultivator tools can be point-hoe/ knife type for narrow band or sweep type for wide band seeding.

\section{References}

1 Bartalos T, Lal R, Németh T, Conservation tillage for sustaining soil and water quality, Ministry for Environment and Regional Policy, AKAPRINT, Budapest, 1995.

2 Bánházi J, Fülöp G, Energiatakarékos talajmúvelési rendszerek, Mezőgazdasági Kiadó, Budapest, 1982.

3 Birkás M, Környezetkímélő és energiatakarékos talajmûvelés (Birkás Márta és tsai, ed.), AKAPRINT Nyomdaipari Kft., Gödöllő, 2002, pp. 345.

4 Birkás M, Kalmár T, Fenyvesi L, Földesi P, Realities and beliefs in sustainable soil tillage systems - A research approach, Cereal Research Communications 35 ( June 2007), no. 2, 257-260.

5 Carter L M, Wheel traffic is costly, Transactions of the ASAE 28 (1985), no. 2, 430-4.

6 Carter L M, Meek B D, Rechel B D, Zone production system for cotton: soil response., Transactions of the ASAE 34 (1991), no. 2, 354-360.

7 Climsoil Report, Review of existing information on the interrelations between soil and climate change, 2008. EU. Final Report 208p.

8 Jori J I, Tillage Intensity and Tillage-Induced $\mathrm{CO}_{2}$ Loss, Progress In Agricultural Engineering Sciences, Akadémiai Kiadó, Budapest, 2004, pp. 35-45. Sample Issue.

9 Lal R, Residue management, conservation tillage and soil restoration for mitigating greenhouse effect by $\mathrm{CO}_{2}$-enrichment, Soil \& Tillage Research 43 (1997), 81-107.

10 Mitchell J P, Lanini W T, Temple S R, Conservation tillage initiatives in California, Proc of Conservation Tillage 2000, Conservation Tillage Success Stories from around the US, Davis, CA. UC Davis, 2000, pp. 83.

11 Reicosky D C, Tillage and short-term $\mathrm{CO}_{2}$ emissions from soils in the laboratory, 1998. Manuscript.

12 Ugalde D, Brungs A, Kaebernick M, McGregor A, Slattery B, Implications of climate change for tillage practice in Australia, Soil and Tillage Research 97 (2007), 318-330.

13 Várallyay Gy, A talaj vízgazdálkodásának szabályozása, mint a környezetkímélő növénytermesztés egyik kulcskérdése, Növénytermesztés és környezetvédelem (Ruzsányi L, Pepó P, eds.), MTA Agrártudományi Osztály, Budapest, 1999, pp. 56-64. 